\title{
Quaking Aspen in Utah: Integrating Recent Science with Management
}

\author{
By Paul C. Rogers and Samuel B. St. Clair
}

\section{On the Ground}

- Quaking aspen is widely regarded as a key resource for humans, livestock, and wildlife with these values often competing with each other, leading to overuse of aspen in some locations and declines.

- We review trends in aspen science and management, particularly in Utah. Historically, research conducted here holds a prestigious place in international aspen circles.

- We highlight recent studies continuing the tradition to keep rangeland managers informed of important developments, focusing on aspen functional types, historical cover change and climate warming, ungulate herbivory, and disturbance interactions.

Keywords: populus tremuloides, ungulate, herbivory, fire, biodiversity, research.

Rangelands 38(5):266-272

doi: 10.1016/j.rala.2016.08.009

(C) 2016 The Society for Range Management

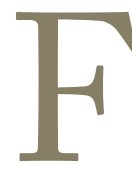

rom the boreal forest in the north to central Mexico and from the Pacific Coast to New England, quaking aspen (Populus tremuloides Michx.) is the most widespread tree species on the North American continent. The media often trumpets the impending doom of aspen in the American West, yet in Utah we commonly see thriving aspen forests accenting high elevation conifer and meadow landscapes. Groves of 'quakies' not only provide valued forage for livestock, they also offer rich biodiversity, water storage capacity, wildlife habitat, aesthetic elements, recreation uses, and fire protection. It is important for us to understand what is happening to aspen in our area, what factors affect their condition, and what prescriptions can be taken to increase ecosystem resilience in aspen forests. As with many complex natural resource issues, restoration of critical ecological processes (e.g., sustainable plant-animal interactions, disturbance regimes, soil development) that interact with competing human needs requires informed participation by a wide contingent of stakeholders.
Science and management of quaking aspen forests is rapidly evolving and much of that development is playing out in Utah ${ }^{\mathrm{i}}$. This follows a long tradition of aspen research originating in the state. ${ }^{1,2}$ A key, long-established, tenant of aspen ecology is the species' capacity to reproduce both asexually via root suckers and sexually from seed germination. Large groups of aspen trees may be genetically identical clones, many of them still connected by root networks. Traditional practices rely heavily on swift suckering responses following burning or cutting, ${ }^{3}$ but until recently less notice has been paid to the management rammifications of seedling establishment. ${ }^{4}$ Another, perhaps less appreciated, cornerstone of aspen sciences is that stands come in two primary forms (Fig. 1): seral (meaning they are relatively short-lived and eventually overtopped by competing conifers) and stable (not competing with conifers, long-term growth in pure or nearly pure stands of aspen). ${ }^{5}$ These overarching themes, reproduction and aspen function, are critical to restorative practices, otherwise well-intended actions may lead to aspen loss. ${ }^{6}$

This survey of quaking aspen literature in Utah updates range managers on developments in the field with an eye toward improved and adaptive practices. Seminal works of the past made great strides in translating the findings of aspen research to field practitioners. ${ }^{1,2}$ More recently, we helped produce a compendium of review articles for a Special Issue of Forest Ecology and Management ${ }^{\mathrm{ii}}$. Our objectives in the present work are to use these sources, alongside more recent efforts, to examine aspen science as it applies to management within the context of Utah. Specifically, we will: 1) examine key issues affecting aspen communities in the state, 2) explore recent developments in the aspen sciences, much of it centered within Utah, and, 3) place the first two objectives in the context of changing management perspectives. This timely update should spur rangeland, forest, and wildlife managers to engage researchers working in the field, as well as inspire

${ }^{\mathrm{i}}$ The 70th Annual Society of Range Management Annual Meeting will be held in St. George, Utah 29 January-2 February 2017. This article highlights Utah range science and management. For more information on SRM Red Rock \& Rangelands 2017 see http://rangelands.org/srm17/.

ii S. St. Clair, P. Rogers (eds.) Resilience in Quaking Aspen: restoring ecosystem processes through applied science. 2013. Forest Ecology and Management, Vol. 299. http://www.sciencedirect.com/science/journal/ 03781127/299. 
A

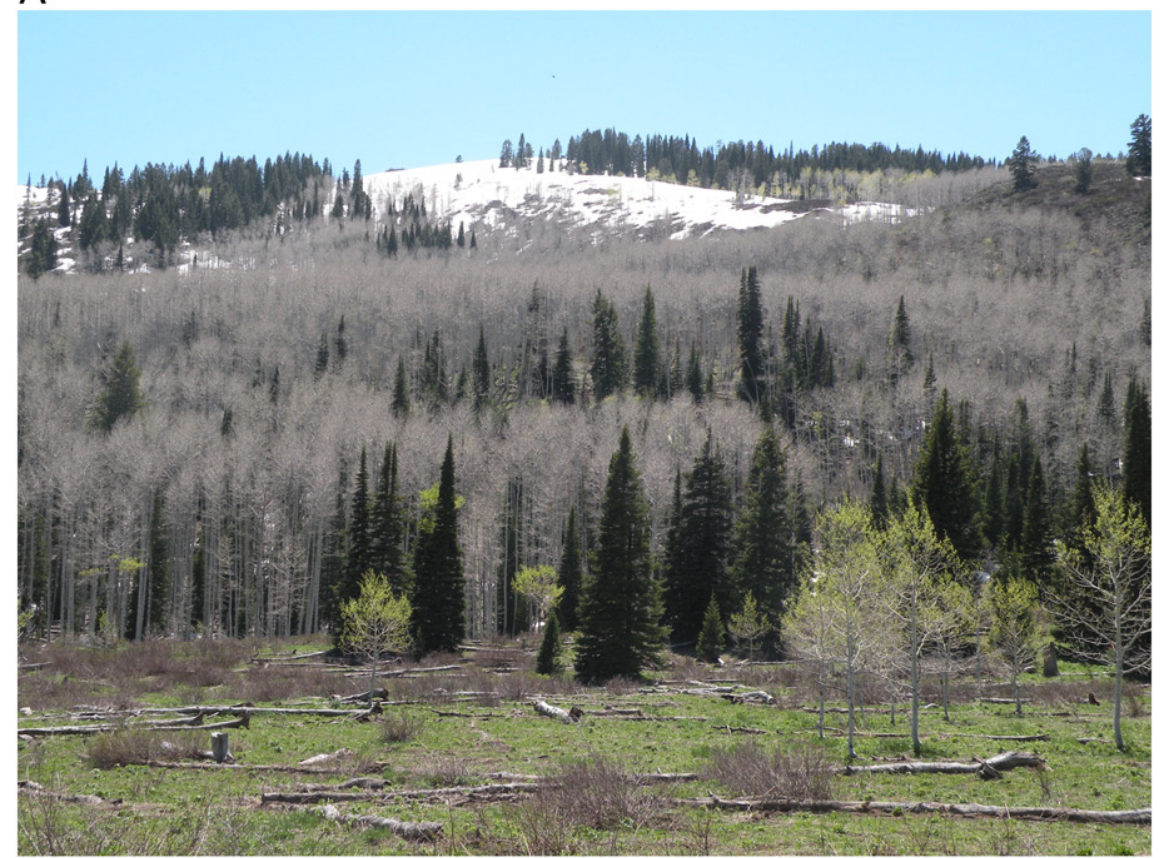

B

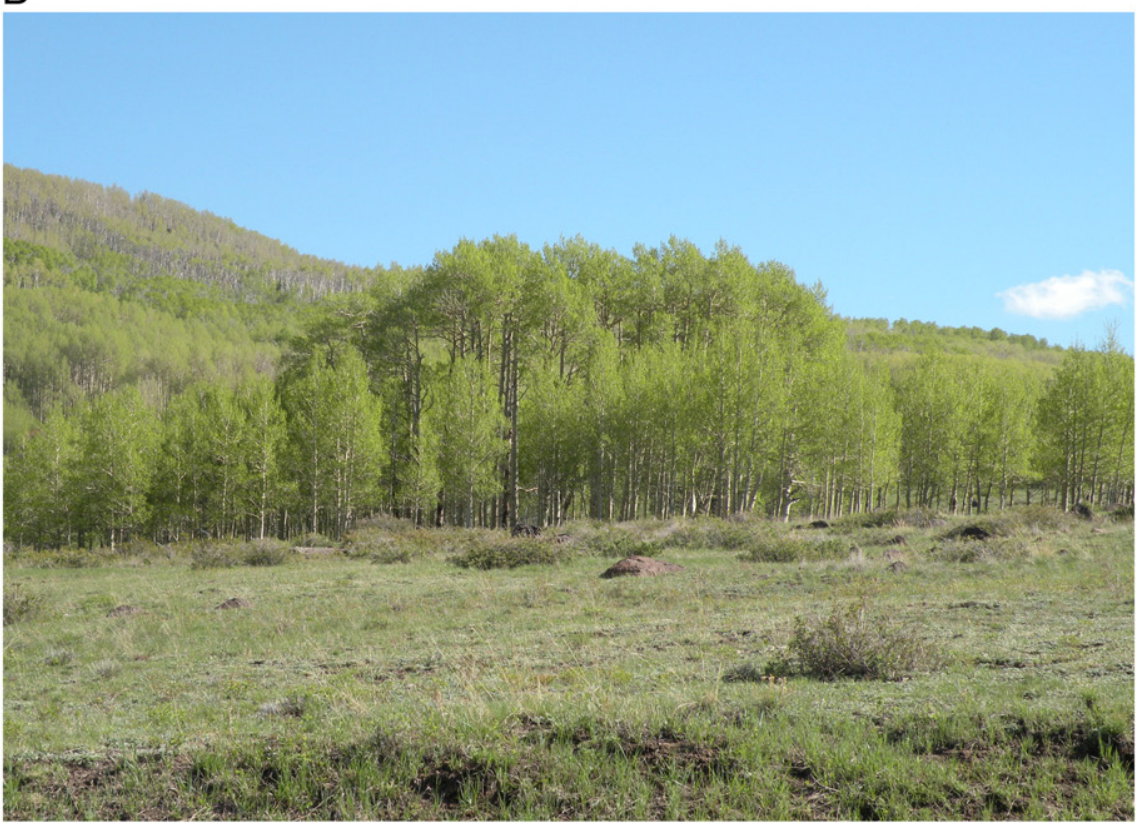

Figure 1. Two primary aspen functional types occur in Utah. A, Seral aspen, in the absence of disturbance will eventually be over-topped by competing conifers. The photo is from Logan Canyon, in northern Utah, and depicts a seral stand in mid-succession with subalpine fir (Abies lasiocarpa Nutt.) in early spring. B, Stable aspen refers to long-term dominance by aspen, with little or no presence of other tree species, and generally not subject to stand-replacing disturbance. This picture shows a stable aspen community on Boulder Mountain, south-central Utah.

collaboration across managerial and agency lines, toward benefiting the state's aspen resources at-large.

\section{Key Issues}

Cover Change, Climate Warming

We often hear about a great change in aspen cover since Euro-American settlement or the imminent demise (a.k.a., 'sudden decline') of contemporary aspen. While there is some truth to such claims, in reality aspen extent and health across Utah are quite variable. Nonetheless, early post-settlement influences across the state did leave an imprint; settlers used fire abundantly to clear land after logging and create forage following often intense grazing. ${ }^{7}$ Similarly, at least in northern Utah, unregulated hunting depleted large herbivores like elk by the early $20^{\text {th }}$ century, ${ }^{8}$ which likely had positive effects on aspen recruitment. Cessation of burning practices, by natives and settlers alike, as well as implementation of fire suppression by 


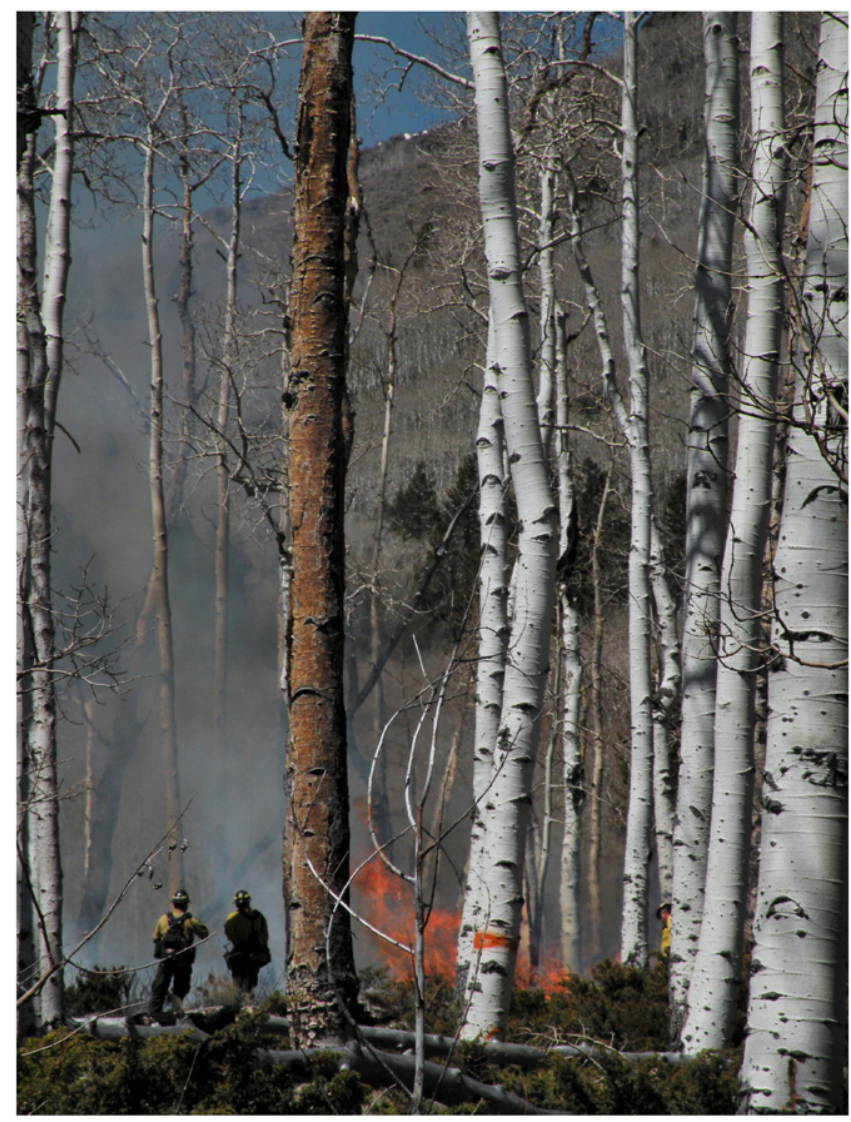

Figure 2. Prescribed burning at the Pando clone, near Fish Lake, Utah, was part of an experimental treatment regime to test regeneration response, fencing, and monitoring methods. Recent mortality of mature trees combined with long-term herbivory patterns has posed a threatening situation to the survival of this iconic aspen clone, currently thought to be the largest living organism on earth.

state and federal agencies, quickly reversed these positive trends and persisted through most of the next 100 years. There is debate if fire suppression had widespread impacts on aspen communities, as the $20^{\text {th }}$ century was unusually wet climatically, and much of this time suppression techniques were variably effective depending on forest types and firefighter accessibility. ${ }^{9,10}$ Regardless of cause, many seral aspen communities witnessed a decline over this period as conifer succession advanced. Stable communities were largely unaffected due to their limited flammability. ${ }^{10}$ Because seral aspens are more common in Utah, an overall reduction of aspen cover likely resulted. ${ }^{11}$ This trend might be expected to reverse as warming temperatures are predicted to increase wildfire, which favors aspen renewal at some locations, while associated drought may limit aspen habitat at vulnerable low elevation sites. ${ }^{12}$

\section{Ungulate Herbivory}

Quaking aspen stands are widely revered by range and wildlife managers alike for their high productivity and nutrition of the understory forage. Young aspen suckers are utilized as forage by deer, elk, cattle, and sheep. Late in the growing season aspen are a particularly important forage source for ungulates. ${ }^{13}$ Fortunately,

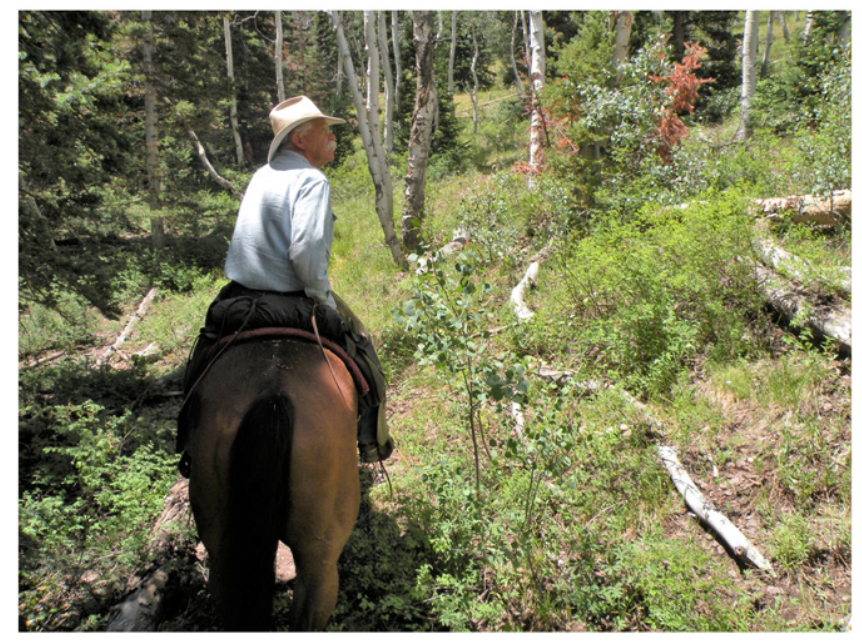

Figure 3. A horseman surveys an area on Monroe Mountain, central Utah, where cattle grazing has been absent for several decades. In this case, adequate recruitment is occurring (note tall regeneration at riders chest level) in seral aspen; uphill, where slope angles are lower and stable aspen dominate, elk browsing has nearly eliminated regeneration. Costs associated with intensive surveys, as well as temporary limits on domestic and wild ungulate use, are among the difficult tradeoffs being considered to ensure sustainable aspen resources.

aspen leaves contain defense compounds (phenolic glycosides and condensed tannins) that may reduce herbivores, at least partly, from devouring young suckers. ${ }^{14}$ Aspen genotypes (clones) differ in their level of defense compounds. ${ }^{15}$ However, with high animal concentrations - often a mix of wild and domestic herbivores on the same landscape - defense mechanisms may not sufficiently deter browsing on regenerating aspen. If these consumption patterns persist over many years, aspen forests tend to lose their younger age cohorts resulting in stands with less structural complexity. This situation seems most serious in stable aspen forests where uncommon large disturbances offer little prospect of broad forest regeneration.

The giant "Pando" aspen clone in central Utah is a prime example of a stable aspen community threatened by herbivory. This 106 acre, genetically identical, stand of approximately 47,000 stems was first identified in the 1970s using physical traits and later confirmed by advanced genetic techniques. ${ }^{16,17}$ Though we cannot precisely determine the age of the entire Pando clone, individual stems of mature trees are between 100 and 120 years old. There are very few stems younger than this and stable aspen forests are dependent on complex age and size structure for resilience against abiotic and biotic stress. ${ }^{6}$ Browsing by cattle and deer in the Pando clones appear to have severely limited regrowth of young aspen suckers over recent decades, and mature trees are rapidly dying off resulting in a critical state of affairs for this iconic grove. ${ }^{13}$ (Thus far, we have been unable to find clear evidence that elk are browsing at Pando.) Currently, efforts by the U.S. Forest Service to protect regrowth of the clone from browsers are underway, but vigilance in adaptive monitoring and management will be imperative if Pando is to be preserved (Fig. 2).

At a broader scale, browsing by livestock and wildlife are affecting long-term sustainability of aspen to varying degrees. ${ }^{18}$ 
The combination of drought and herbivory poses a significant problem for many aspen forests. For example, a large-scale study examined the effects of cattle and deer on drought-prone forests in the Book Cliffs region of eastern Utah and found that nearly all stands exhibited non-sustainable levels of recruitment. ${ }^{19}$ In this instance, elk use correlated highly with greater browse levels (the strength of this correlation was about twice that of cattle and deer). Across Cedar Mountain in southern Utah, where cattle are uncommon and wild ungulate populations are relatively small, sheep utilization appears to play a larger role in limiting aspen recruitment. ${ }^{20} \mathrm{~A}$ recent survey of aspen regeneration in stable aspen forests across central and southern Utah found that $60 \%$ of surveyed stands had low levels of ungulate browsing with high recruitment, $32 \%$ had intermediate levels of browsing with some evidence of recruitment, and $8 \%$ exhibited recruitment failure due to ungulate browsing (Rhodes and St. Clair, unpublished).

Several different management approaches have been proposed in areas with high ungulate use. The presence of large carnivores, such as wolves, grizzly bears, and cougars, may deter aspen browsing by keeping livestock and wildlife on the move. ${ }^{18}$ Domestic livestock may be more easily herded to prevent over-browsing of aspen, although this intensified management will likely increase costs for producers. Range and wildlife managers are now working collaboratively to curtail recruitment failure while continuing to sustainably utilize forage resources. Increasing targeted elk hunts where monitoring demonstrates poor recruitment, as well as potential hazing by range riders are two options that may successfully curtail overbrowsing by wild ungulates. Where wild and domestic species overlap (spatially and seasonally) innovative strategies such as pasture rotations and longer rest periods (i.e., 3-5 years) may be combined with elevated hunting levels. Such practices should be closely coordinated with active monitoring to gauge the progress of new aspen recruitment on threatened aspen landscapes (Fig. 3). Cooperative research and monitoring, as well as prudent use of fire, tree harvest, and post-treatment protection, will be required to increase aspen recruitment in areas with high ungulate herbivory.

\section{Disturbance Interactions}

Aspens normally respond well to disturbance, often regenerating vigorously through root suckering following such events. Climate has a stronger influence on wildfire ignitions and extent than fire suppression, though fire suppression is often cited as a chief cause of long-term aspen decline. The $20^{\text {th }}$ century was unusually wet for Utah (and much of the West) and as a result of this pattern of fire occurrences and sizes were relatively limited. ${ }^{7}$ However, more recent trends describe a changing pattern of precipitation-specifically, similar overall precipitation, but less as snow and more as rain, and earlier and longer seasonal drying - alongside warming temperatures in the state. ${ }^{21}$ These trends should favor increased and multiple disturbances, such as fire and epidemic insect mortality, that may favor aspen expansion and proliferation. ${ }^{22}$ In contrast, other researchers focusing on aspen habitat describe a scenario of shrinking aspen cover with a warming climate. ${ }^{23}$ There is further support for dieback attributed to acute drought and physiological collapse based on root cavitation (plant cell embolism with water deficiency), ${ }^{24}$ however, while this phenomenon has been demonstrated in local areas it remains to be seen if such processes will overwhelm opposing positive influences expected with warming trends. We expect further research will improve our understanding, although it is likely that both aspen expansion related to increased disturbance and cover reduction resulting from shrinking habitat will interact in complex ways across Utah.

Recent research in aspen forests of Utah suggests that appropriate management of fire can increase the resilience of seral aspen forests. Aspen facilitates the establishment of conifer seedlings around their trunk base, which over time grow into mixed conifer-aspen stands. ${ }^{25}$ This establishment and expansion of conifers in close proximity to aspen trees creates competition for light and soil resources ${ }^{26}$ that increase aspen mortality rates in mid to late stages of succession. ${ }^{27}$ With advancing succession, the probability of fire increases dramatically due to the high flammability of conifers. However, if fire return intervals lengthen due to wetter climate periods or human suppression of fire, aspen mortality increases as regeneration capacity decreases. ${ }^{25}$ To improve the resilience of aspen forests recent work suggests limiting fire suppression in seral aspen while increasing prescribed fire long before late seral conditions (i.e., $<10 \%$ aspen density) if a strong aspen regeneration response is desired. ${ }^{28}$

Fire management can also play a critical role in increasing the resilience of aspen forest to ungulate herbivory according to recent studies conducted in Utah. This research posits that larger and more severe fires increase the resistance and tolerance of regenerating aspen to browsing by elk, deer, and cattle. ${ }^{29,30}$ Data show that aspen regeneration density and growth are greater following high severity fires, and that mammal browsing is lower partially due to aspen leaves containing higher concentrations of defense compounds. ${ }^{31}$ Regenerating aspen prefer sunlight, thus the strong growth response to high burn severity is at least partially driven by higher light conditions with overstory loss. However, there is also evidence that a loss of vegetation that ungulates use for cover and thermoregulation may limit habitat desirability. ${ }^{32}$ The positive effects of fire size are likely related to a browser dilution effect in which post-fire regeneration of aspen over a larger area saturates the browsing capacity of the ungulate community. ${ }^{33}$ These results suggest that larger, more severe fires increase the likelihood of successful aspen regeneration and recruitment in areas with intense browse pressure.

As we examine key issues as a whole, they may be seen as impediments to resilience that must be addressed as we face an uncertain future. Many of these issues are being directly examined in an applied context within Utah. A closer look at Utah-based research, integrated with broader aspen advances, describes a dynamic picture of an evolving field in which science and management in this state is playing a vital role.

\section{Utah-Based Aspen Research}

Aspen-related research within Utah has a long and prestigious history. Recent advances in the aspen sciences are augmenting that record. The following is a compendium of 
brief updates on local research that is informing our understanding of aspen forests:

Functional management. Further clarity has developed around an old idea developed in Utah that not all aspens 'behave' alike. ${ }^{6}$ More recent work has clarified that there are distinct climatological, as well as ecological, niches among distinct aspen 'types'. ${ }^{6,26}$ Stable aspens are more prone to drier sites with lower slope angles, though there is considerable environmental overlap with seral communities. ${ }^{26}$ Classification of aspen landscapes by functional characteristics is intended to aid appropriate management prescriptions that more closely emulate the natural processes, thereby increasing chances of higher long-term restoration success. ${ }^{8}$

Soil and carbon balance. Researchers at Utah State University have been investigating the role of soil health in aspen and conifer stands. Specifically, they have documented greater long-term storage of soil organic carbon in stands that remain aspen-dominant. ${ }^{34}$ Greater quantities of silt and clay facilitate carbon storage and sequestration. This work suggests the benefits of managing for aspen include increases of $25 \%$ to $30 \%$ more mineral-associated soil organic carbon when compared to adjacent conifer-dominated stands. ${ }^{34}$ More generally, forest soils are an important ecological link to aspen conditions, and research in this area remains in its infancy. In addition to the important role carbon sequestration plays, we recommend greater focus on soils research related to biodiversity, soil retention, and water conservation.

Species facilitation. Perhaps the greatest benefit of aspen forests is that they support very high levels of understory plant diversity. ${ }^{28}$ Bowns and Bagley documented the severe transformation of understory communities in southern Utah as a result of long-term grazing. ${ }^{33}$ This richness is not only valued by livestock producers, it facilitates broader avian, mammal, and insect diversity. ${ }^{35}$ Even arboreal lichens benefit from the presence of aspen on the landscape. ${ }^{36}$ Among tree species, there is evidence from Utah to suggest that aspens facilitate establishment and growth of conifer seedlings, ${ }^{25}$ positing that loss of aspen forest may lead to loss of forest cover more broadly, at least as it affects some associate tree species.

Regeneration ecology. Recent advances in our understanding of aspen ecology include studies in Utah showing that multiple factors affect aspen regeneration success including fire characteristics, ${ }^{31}$ ungulate browsing, ${ }^{18}$ conifer expansion, ${ }^{25}$ and genetics. ${ }^{37}$ The success of aspen regeneration due to these factors then has cascading effects on the establishment success of associated conifer species that likely has strong impacts on the composition of the forest overstory and understory over time. ${ }^{34}$

Chemical defense. Numerous works have shown that defensive chemical compounds found in aspen leaves and shoots are closely related to genotype. ${ }^{15}$ Research conducted in Utah in the last few years has demonstrated that the expression of defense compounds in aspen leaves varies depending on fire severity, ${ }^{32}$ low light conditions due to conifer expansion, ${ }^{27}$ cold temperatures, ${ }^{38}$ and pathogen attack (Call and St. Clair, unpublished). Higher production of phenolic glycosides in aspen leaves can decrease the browsing preference of elk and sheep. ${ }^{15,39}$ Based on this information it may be possible to re-establish aspen in areas with chronic ungulate browsing by using aspen genotypes with higher production of defense compounds or higher browse tolerance. The authors recognize that there are significant barriers to out-planting of aspen that must still be addressed in order to facilitate such a strategy.

\section{Changing Perspectives and Management Implications}

Conventional treatments to stimulate aspen regeneration are widely available, ${ }^{2,4,6}$ although we now know, given even modest herbivory, that a strong suckering response is often not enough to protect from post-treatment browsers. In order to sustain aspen on the landscape, land stewards are adopting "resilience management" strategies. In essence, this entails preserving options. Where fire was historically an important regenerative tool in seral aspen, judicious use of selective harvest practices and prescribed and wildland fire management may be invoked. A key component of resilience management means understanding ecological function: not all aspen stands are alike in terms of their ecology and earlier human impacts. ${ }^{6}$ Treating aspen as a "one-size-fits-all" prospect may cause irreversible damage. Thus, locally-based knowledge, current science, ongoing monitoring, course correction (where necessary), and institutional support-all key elements of "adaptive management"-provide a framework for resilience. The complexity of resilience management will require multiple disciplinary perspectives if it is to be successful. These approaches will become particularly important with further climate warming and increased disturbance in the West.

In any endeavor that includes multiple stakeholders there will be tradeoffs required to achieve ecological resilience in aspen that are compatible with human interests. First, we should be clear that not all aspen forests are in need of restoration in Utah. Many locations, commonly those at upper elevations where moisture is abundant and herbivory is limited, support thriving and diverse aspen systems. Second, the prospect of climate warming should not be invoked in a defeatist manner in which managers feel there is little that can be done. Managing for resilience does not mean resisting change or giving up; it does imply restoring sustainable conditions so that aspen forests have the greatest chance of responding positively to future conditions. We understand that the task of preserving Utah's state tree will involve compromise and sacrifice by all stakeholders where actions are required. If restoring a rich forage in aspen landscapes is important to the livestock industry, as well as wildlife, recreation, and water conservation interests, there may be costs today that will preserve options for tomorrow. Such costs may include creative solutions, such as intensive rest/ rotation approaches, temporarily reduced ungulate populations in areas of poor recruitment due to herbivory, allowance for more wildfire, temporary closures while aspens recover from 
resource use, and even agency, industry, and private monetary contributions to improved management practices.

This article provides an update to aspen research and management within Utah. While earlier research efforts here played a major part in describing foundational concepts in aspen ecology, several recent advances have lead us to reexamine conventional practices. As described here, aspen forests are more diverse, both genetically and functionally, than many managers have assumed. These variances point toward important adjustments that may be required of managers if they are to responsibly address aspen issues such as domestic and wild ungulate herbivory, fire suppression, appropriate grazing and silviculture strategies, and changing drought and temperature patterns. Ecologically appropriate practices toward resilient communities - inclusive of myriad obligate plants and animals - should be the overarching goal of contemporary aspen management. While the current work focuses on activities in Utah, we believe much of the content herein applies broadly. In particular, $21^{\text {st }}$ century aspen management should begin with a clear understanding of distinct aspen communities and base land use actions on a system of adaptive, data driven practices. We encourage multidisciplinary collaborations, where practical, as aspen ecosystem conditions affect diverse resource interests. The future of effective aspen management will be dependent on regular, informed, and respectful exchanges between academic, professional, and vocational arenas. Thus, science has an important role to play in informing contemporary range managers regarding aspen ecology and resource decisionmaking. Our hope is that this review has provided a scientific foundation for range managers as they address important, often complex, resource issues involving Utah's state tree, the quaking aspen.

\section{Acknowledgments}

The authors would like to thank Dr Mary Anne Hedrich for providing helpful pre-submission editorial review. Thanks to two anonymous reviewers for helpful comments toward a marked improvement of this manuscript.

\section{References}

1. BAKER, F. S. 1925. Aspen in the central Rocky Mountain region. Washington, DC, USA: U.S. Department of Agriculture. Bulletin No. 1291.

2. DeByle, N. V., And R. P. Winokur. 1985. Aspen: ecology and management in the western United States. Fort Collins, CO, USA: U.S. Department of Agriculture, Forest Service, Rocky Mountain Forest and Range Experiment Station. RM-119.

3. Schier, G. A., J. R. Jones, and R. P. Winokur. 1985. Vegetative regeneration. In: N. V. DeByle and R. P. Winokur. [Eds.]. Aspen: ecology and management in the western United States. Fort Collins, CO, USA: U.S. Department of Agriculture, Forest Service, Rocky Mountain Forest and Range Experiment Station. RM-119. 29-33 pp.

4. Long, J. N., AND K. Mock. 2012. Changing perspectives on regeneration ecology and genetic diversity in western quaking aspen: implications for silviculture. Canadian Journal of Forest Research 42:2011-2021.
5. BAKeR, F. S. 1921. Two races of aspen. Journal of Forestry 19:412-413.

6. Rogers, P. C., S. M. Landhäusser, B. D. Pinno, and R. J. RYEL. 2014. A functional framework for improved management of western North American aspen (Populus tremuloides Michx.). Forest Science 60:345-359.

7. Rogers, P. C., D. L. Bartos, and R. J. Ryel. 2011. Historical patterns in lichen communities of montane quaking aspen forests. In: J. A. Daniels. [Ed.]. Advances in environmental research. Vol. 15. Hauppauge, NY, USA: Nova Science Publishers, Inc. pp. 33-64.

8. Toweill, D. E., and J. W. Thomas. [Eds.] 2002. North American elk: ecology and management. Washington, DC, USA: Smithsonian Institution Press. pp. 109-110.

9. BAKer, W. L. 2009. Fire ecology in Rocky Mountain landscapes. Washington, DC, USA: Island Press. pp. 178-187.

10. Shinneman, D. J., W. L. Baker, P. C. Rogers, and D. KulaKowsKi. 2013. Fire regimes of quaking aspen in the Mountain West. Forest Ecology Management 299:22-34.

11. Bartos, D. L., and R. B. J. Campbell. 1998. Decline of quaking aspen in the Interior West-examples from Utah. Rangelands 20:17-24.

12. Yang, J., P. J. Weisberg, D. J. Shinneman, T. E. Dilts, S. L. Earnst, and R. M. Scheller. 2015. Fire modulates climate change response of simulated aspen distribution across topoclimatic gradients in a semi-arid montane landscape. Landscape Ecology 30:1055-1073.

13. Rogers, P. C. 2016. Saving pando: humans are taking measured steps to rejuvenate an ailing giant. Natural History 124:32-37.

14. Villalba, J. J., E. A. Burritt, and S. B. S. Clair. 2014. Aspen (Populus tremuloides Michx.) intake and preference by mammalian herbivores: the role of plant secondary compounds and nutritional context. Journal of Chemical Ecology 40:1135-1145.

15. Lindroth, R. L., And S. B. St. Clair. 2013. Adaptations of quaking aspen (Populus tremuloides Michx.) for defense against herbivores. Forest Ecology Management 299:14-21.

16. Kemperman, J. A., And B. V. Barnes. 1976. Clone size in American aspens. Canadian Journal of Botany 54:2603-2607.

17. DeWoody, J., C. A. Rowe, V. D. Hipkins, and K. E. Mock. 2008. "Pando" lives: molecular genetic evidence of a giant aspen clone in central Utah. Western North American Naturalist 68:493-497.

18. Seager, S. T., C. Eisenberg, and S. B. St. Clair. 2013. Patterns and consequences of ungulate herbivory on aspen in western North America. Forest Ecology Management 299:81-90.

19. Rogers, P. C., And C. M. Mittanck. 2014. Herbivory strains resilience in drought-prone aspen landscapes of the western United States. Journal of Vegetation Science 25:457-469.

20. Rogers, P. C., A. J. Leffler, And R. J. Ryel. 2010. Landscape assessment of a stable aspen community in southern Utah, USA. Forest Ecology Management 259:487-495.

21. Gillies, R. R., H.-Y. Wang, and M. R. Booth. 2012. Observational and synoptic analyses of the winter precipitation regime change over Utah. Journal of Climate 25:4679-4698.

22. Kulakowski, D., C. Matthews, D. Jarvis, and T. T. Veblen. 2013. Compounded disturbances in sub-alpine forests in western Colorado favour future dominance by quaking aspen (Populus tremuloides). Journal of Vegetation Science 24:168-176.

23. Worrall, J. J., G. E. Rehfeldt, A. Hamann, E. H. Hogg, S. B. Marchetti, M. Michaelian, and L. K. Gray. 2013. Recent declines of Populus tremuloides in North America linked to climate. Forest Ecology Management 299:35-51.

24. Anderegg, W. R. L., L. Plavcová, L. D. L. Anderegg, U. G. Hacke, J. A. Berry, and C. B. Field. 2013. Drought's legacy: multiyear hydraulic deterioration underlies widespread aspen forest die-off and portends increased future risk. Global Change Biology 19:1188-1196. 
25. St. Clair, S. B., X. Cavard, and Y. Bergeron. 2013. The role of facilitation and competition in the development and resilience of aspen forests. Forest Ecology Management 299:91-99.

26. Mittanck, C. M., P. C. Rogers, R. D. Ramsey, D. L. Bartos, AND R. J. RYEL. 2014. Exploring succession within aspen communities using a habitat-based modeling approach. Ecological Modelling 288:203-212.

27. Calder, W. J., K. J. Horn, and S. B. St. Clair. 2011. Conifer expansion reduces the competitive ability and herbivore defense of aspen by modifying light environment and soil chemistry. Tree Physiology 31:582-591.

28. Calder, W. J., and S. B. St. Clair. 2012. Facilitation drives mortality patterns along succession gradients of aspen-conifer forests. Ecosphere 3:57.

29. Chong, G. W., S. E. Simonson, T. J. Stohlgren, And M. A. Kalkhan. 2001. Biodiversity: aspen stands have the lead, but will nonnative species take over? In: W. D. Shepperd, D. Binkley, D. L. Bartos, T. J Stohlgren, and L. G. Eskew. [Eds.]. Sustaining aspen in western landscapes. Grand Junction, CO, USA: U.S. Department of Agriculture, Forest Service, Rocky Mountain Research Station. RMRS-P-18. 261-271 pp.

30. Smith, E. A., D. O'Loughlin, J. R. Buck, and S. B. St. Clair. 2011. The influences of conifer succession, physiographic conditions and herbivory on quaking aspen regeneration after fire. Forest Ecology Management 262:325-330.

31. Wan, H. Y., A. C. Olsen, K. D. Muncey, and S. B. St. Clair. 2014. Legacy effects of fire size and severity in forest regeneration, recruitment and wildlife activity in aspen forests. Forest Ecology Management 329:59-68.

32. Wan, H. Y., A. C. Rhodes, and S. B. St. Clair. 2014. Fire severity alters plant regeneration patterns and defense against herbivores in mixed aspen forests. Oikos 123:1479-1488.

33. Dobarco, M. R., and H. Van Miegroet. 2014. Soil organic carbon storage and stability in the aspen-conifer ecotone in montane forests in Utah state, USA. Forests 5:666-688.
34. Bowns, J. E., AND C. F. BAgLEY. 1986. Vegetation responses to long-term sheep grazing on mountain ranges. Journal of Range Management 39:431-434.

35. BAILEY, J. K., AND T. G. Whitham. 2003. Interactions among elk, aspen, galling sawflies and insectivorous birds. Oikos 101:127-134.

36. Holt, E. A., N. Zemp, M. Van Orman, J. Perry, B. T. Williams, And M. Ogden. 2015. Macrolichen substrate selection: Patterns among aspen, non-aspen hardwood, and coniferdominated forests in the Wasatch Mountains, Utah. Bryologist 118:357-366.

37. St. Clair, S. B., K. E. Mock, E. M. LaMalfa, R. B. Campbell, and R. J. Ryel. 2010. Genetic contributions to phenotypic variation in physiology, growth and vigor of western aspen (Populus tremuloides) clones. Forest Science 56:222-230.

38. St. Clair, S. B., S. Monson, E. A. Smith, D. G. Cahill, and W. J. CAlder. 2009. Altered leaf morphology, leaf resource dilution and defense chemistry induction in frost defoliated aspen (Populus tremuloides). Tree Physiology 29:1259-1268.

39. Wooley, S. C., S. Walker, J. Vernon, and R. L. Lindroth. 2008. Aspen decline, aspen chemistry, and elk herbivory: are they linked? Rangelands 30:17-21.

Authors are Director, Western Aspen Alliance, Ecology Center Associate, Wildland Resources Department, Utah State University, Logan UT 84322 (Rogers, p.rogers@usu.edu); and Associate Professor, Plant Eo Wildlife Sciences, Brigham Young University, Provo, UT 84602 (St. Clair). Partial funding for this project [PCR] is provided under USDA Bureau of Land Management agreement number L10AC20552. PCR received support from Utah State University's Wildland Resources Department, Ecology Center, and the Western Aspen Alliance. SBS received support from the Redd Center for Western Studies, the Utah Division of Wildlife Resources, and Brigham Young University. 